\title{
"It's Neighborhood, Not Buildings": Spatial Anchors to Morals and Persons in a Portuguese Housing Project
}

ANA MOURÃ O, Center for Research in Anthropology, Av. Forças Armadas, Edificio

ISCTE-IUL, sala 2W2, 1649-026 Lisbon, Portugal. Email: al.mourao@gmail.com

Personhood can provide "ontological cement" (Hickman 2014) for imagining moral objects since persons are cognitively "more concrete entities" than morals. I examine this proposal in a Portuguese migrant housing project where contrasting moral codes and personhood models coexisted. Local residents (Portuguese and African migrant families formerly living in slums) were involved daily in discrepant discourses and behaviors: strongly defending neighbor sharing while privately condemning it as unfair; monitoring and gossiping about neighbors' possessions to enforce sharing while concealing their own; reinforcing proximity through relatedness idioms while undermining it through distancing rhetoric; seeking mutual assistance while regretting evil and duplicity in proximate relations. I examine this ambivalence in morals and persons in light of an economic and ethical shift in postindustrial capitalist societies and show how the duality was locally reimagined through theories about housing space. Amid moral uncertainty, space became cognitively "more concrete" than persons.

Key words: space, personhood, morals, neighbors, ambivalence, social rehousing, Lisbon, Cape Verdeans

Santos was a 38-year-old Cape Verdean resident in Topia, a migrant housing project in Portugal where I did fieldwork in 2010-2011. It was common to hear Santos reproach his neighbors for being morally wicked, uncaring people. During a walk one afternoon, he again vented: "I hate Topia! I'd put a bomb in every building and blow them all up!" His outburst sounded unremarkable, until he added: "Then I'd move the people to different houses. ..."

Models of the social "person" (Mauss [1938] 1985) appear linked to particular "moral codes" - sets of values, vocabularies, and personal attributes presented as "ethical," good, worthy (Rose 1989:241-43), determinant of the types of claims people can make of each other (Ferguson 2013:236). Hickman (2014:318-22) has recently argued, based on observations among the Hmong in Thailand and the United States, that personhood models can provide "ontological cement" for more abstract and dif-

Submitted April 26, 2016; accepted September 26, 2016; published online April 11, 2017.

Journal of Anthropological Research (Summer 2017). (C) 2017 by The University of New Mexico.

All rights reserved. 0091-7710/2017/7302-0004\$10.00 
fuse moral objects since, for the human imagination, "persons" are arguably "more concrete entities" than "objective moral goods." This interesting proposal deserves ethnographic exploration. But in a world marked by pervasive mobility, and fluid and shifting cultural identities (Inda and Rosaldo 2008), Hickman's argument begs the question: What happens when personhood lacks solid grounding? How are morals and "persons" reimagined locally amid multiplicity, uncertainty, and change? In recent work in South Africa, Ferguson (2013:230) addressed the issue, observing the transformations in personhood following the transition in capitalism "from a people-scarce system to a peoplesurplus one," and how the unavailability of wage labor fostered new paradigms of social dependence.

In this article, I focus on how Topia's residents handled a similar transition: from stable employment, a "work ethic," and perceived neighbor interdependency to material instability, a focus on "consumption" and self-accountability (Bauman 1998). I examine how this shift created ambiguous moral claims and models of duplicitous persons, and how that duality was reinterpreted through spatial metaphors. With discrepant codes and values competing for social validation, I argue that spatial models were used to resolve ambivalence and establish polarized models of morals and persons, through allegories of "shanties" versus "buildings." Amid material and moral uncertainty, space provided in Topia the "ontological cement" for personhood and morals. In other words, space was to the imagination "more concrete" than persons.

This analysis of space as cognitive anchor for morality and personhood also contributes to wider debates in social science on the meanings of space in a world increasingly defined by transnational mobility and unbounded connections (e.g., Gupta and Ferguson 1992; Inda and Rosaldo 2008). Since the 1990s, anthropology saw a renewed interest in space as "an essential component of sociocultural theory" (Low and LawrenceZúñiga 2003:1). However, theorizing about space becomes problematic under the current "transnational" optic (e.g., Englund 2002:262; Gupta and Ferguson 1992:20) because the term's historical connotations of boundedness and fixity are difficult to reconcile with a stress on translocalism and fluidity. By examining how residents used space to build moral certainty by fixing and dichotomizing ambiguous values, I wish to counter the excessive attention paid to the unboundedness of space in social science (Castells 2004; Massey 1997) and reaffirm the relevance of spatial boundaries and its static components in today's mobile world (Pellow 2001).

\section{THE SETTING}

Topia (pseudonym) is a small housing project built in 1999 to rehouse migrant families evicted from shanty settlements in a satellite city of Lisbon. Most families came from the rural countryside and former Portuguese African colonies-mainly Cape Verde (Batalha 2004:133-36)—attracted by growing industrialization and urbanization. They settled on unused land around Lisbon beginning in the 1960s. Low income, combined with cultural-linguistic affinities, friendship networks, and societal racism, encouraged migrants, especially Cape Verdeans, to settle together in shanty towns, 
building houses on unused ground with materials brought from construction sites (Batalha 2008:31-32). They raised their families, or sent for them from abroad (Góis 2008:16), proliferating shanty settlements in the Lisbon outskirts. Although illegal, these slums were overlooked by authorities and rapidly expanded. By the early 1990s, more than 30 such settlements existed in the city where Topia was located (Figure 1).

The situation changed with Portugal's accession to the European Economic Community (later the European Union) in 1986. Alongside profound changes in economy, social values, and discourse (Fikes 2009), poverty and racism became visible in the media and academia, rousing public debate and policy change. According to a 1993 survey, the city where Topia stood consisted of 6,138 squatting households. As the city's demographic boom caused serious housing shortages (with significant contribution of migrant inflows), Europe provided funding and regulation for several programs to tackle the urban housing situation. A government program was launched in the 1990s to eradicate urban shanties and rehouse squatters in appropriate dwellings. Topia was built by the local council with that intent.

The housing estate consisted of parallel rows of white and yellow buildings, four stories high (Figure 2), on the left of an uphill road in the outskirts of the city. A smaller road ran along the estate on the left, bordering empty land used for growing vegetables, sloping down to a nearby highway. Narrow drives and pedestrian streets ran between building blocks. At ground level, stair passages cut through each block, connecting side streets and forming a trail of underpasses parallel to the road.

Close to Topia were bus stops, shops, schools, an elder daycare center, a church, a police station, and the seat of the parish council. The area of the old slums was a bus ride away, as was the center of the suburb where Topia was located, from where the capital Lisbon was easily reached by train. Although Topia was not a ghetto, because it connected both physically and socially with its surroundings, it did have its own social life, with shared expectations on interaction, meaningful codes and knowledge, assistance networks, and a notion of common identity loosely grounded on shared skin color, language (Creole), and residential history.

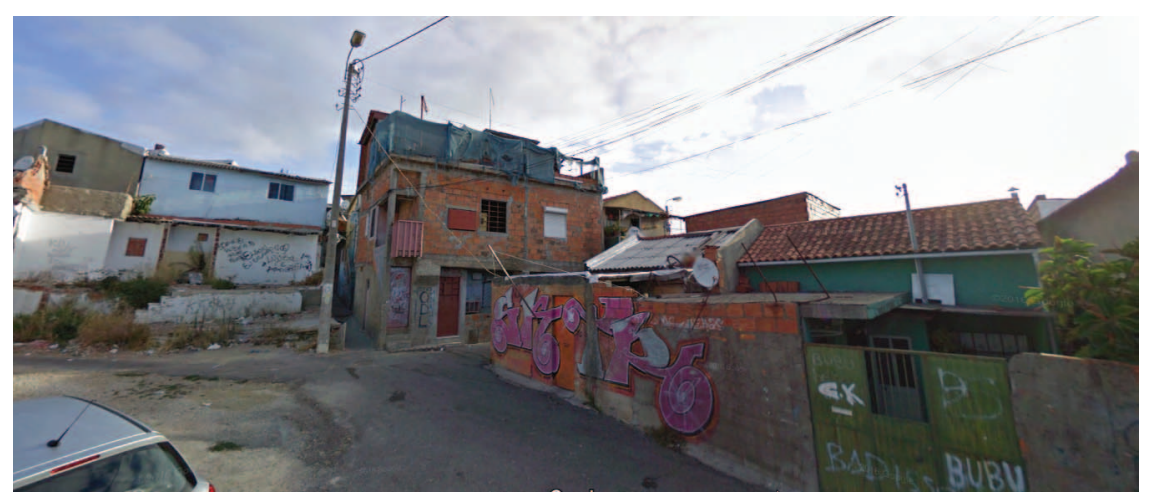

Figure 1. View of a road in one of the shanty towns (Image: Google 2009). 


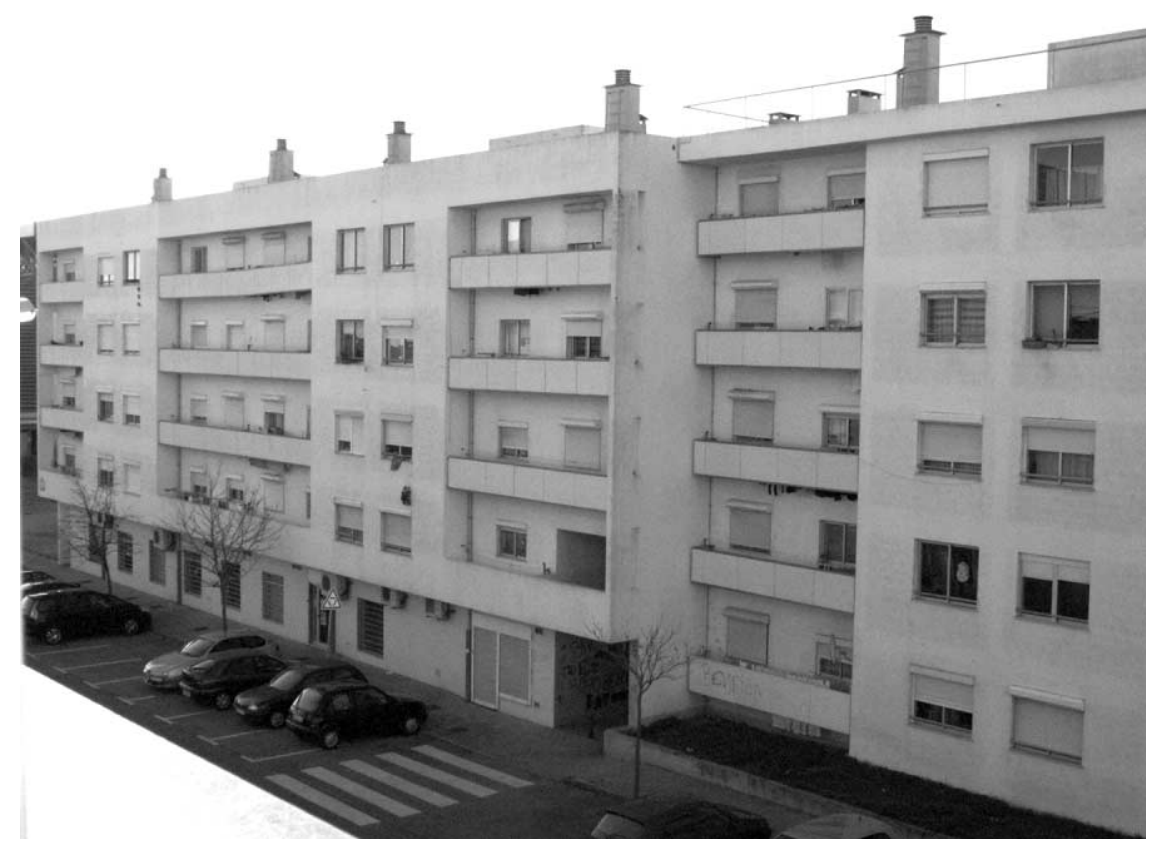

Figure 2. View of a residential streetscape in Topia.

I conducted 14 months of ethnographic fieldwork in Topia, in 2010-2011, grounded on participant observation and complemented by in-depth life-story interviews with 53 residents ( 34 women, 19 men), as well as staff accounts of the main NGOs and state institutions present in the estate. The visible presence of these institutions, namely of social workers regularly checking up on children and controlling means-tested benefits, made direct questions very unwelcome and inquisitive outsiders often feared and mistrusted as covertly working for the state. In this scenario, participant observation was fundamental in building rapport, trust, and allowing gradual penetration of neighborhood routines. It also enabled collection of detailed ethnographic data on everyday practices and interactions beyond - and often in contrast to-normative discourse. Many of the contradictions addressed in this article would not have become evident otherwise. Life accounts also complemented participant observation by adding close insight into residents' personal views on neighborhood life.

All life stories were recorded (with interviewees' consent), although in daily observation field notes were not taken in informants' presence, so as not to disturb the flow of interaction.

Field access progressed slowly, starting from a group of privileged informants and over time expanding my contacts through their extended networks and referrals. Though these networks covered a variety of people and spaces, and enabled interaction with informants of different origins (Cape Verdean, Guinean, Angolan, white Portuguese), 
age groups (from children to elders), migrant generations (from recent arrivals to Portugal up to third generations), genders, and former slums, diverse access constraints determined that ethnography ended up focusing more closely on women's perspectives, second-generation individuals' views (people in roughly their twenties and thirties), and informants of Cape Verdean and (white) Portuguese origin.

\section{THE PEOPLE}

Most families moved to Topia between 2001 and 2004. By 2010, 493 households from 23 different slums lived in the estate. Among these, 78\% of households originated in three neighboring slums. The council let properties at controlled rates, based on housing type and household income. All housing-related matters were managed by council social workers.

The city's housing shortage meant that shanty dwellers were dispersed through different estates, and vacating flats in Topia were readily occupied by newcomers from diverse origins. Still, adult residents tended to socialize more closely within their former slum, and interviewees confirmed that their closest friends were people they grew up with in the shanties. Although the council accommodated some family preferences about keeping shanty neighbors in the new buildings, most adult informants complained about not "really" knowing their neighbors. During my fieldwork, several years after the initial rehousing, some families admitted they had moved willingly to the new buildings, others claimed they would have preferred to stay in the shanties. But among both, a pervasive narrative identified the move with a profoundly negative shift in neighborhood values, sharing practices, and ties: in Topia, people had become "selfish" and "evil."

The rehoused population was very young, with $43.11 \%$ under 24 years old in 2010 . Two thirds of tenants (second and third generations) were born in Portugal and held Portuguese citizenship, with one fifth born in Cape Verde. Topia's population was overall deprived, with high rates of unemployment, or precarious and poorly paid jobs. Most salaries ranged between $€ 200$ and $€ 500$, barely above minimum wage ( $€ 475$ ), with even lower welfare benefits. Most residents had no declared source of income, and unemployment reached an impressive 45\%, compared with $11 \%$ nationally in 2010 (National Institute of Statistics 2012: 5). This translated, in more destitute cases, into households without water, electricity, or enough food intake. For the many families getting by on undeclared or illegal activities (informal vending, prostitution, scavenging, stealing), hardship more often meant reaching mid-month without money, or leaving bills unpaid, or not being able to afford transportation or telephone service.

Hardship was aggravated by the 2008 financial and economic crisis, which strongly hindered construction projects. Approximately $40 \%$ of men in Topia identified their "profession" within the construction sector, which in 2010-2011 alone suffered an 8.7\% decrease in jobs (Gil 2012:11).

Schooling rates in Topia were also low, with high levels of failure and dropout. In 2010 only $5.2 \%$ of respondents had completed high school, with $14.3 \%$ illiterate. 
These and other issues warranted the presence of several institutions in Topia (apart from the housing office) to assist residents with job applications, schoolwork, Internet use, document filling, entrepreneurship training, and sexual-health counselling. While the council and parish facilitated access to direct material aid to 163 households (through Social Security and the Food Bank), most organizations focused on promoting employment and schooling.

Aside from financial aid, residents mostly showed difficulty or resistance to seeking institutional help. Limited knowledge, illiteracy, mistrust of outsiders, and a sense of neighborhood complicity made family and neighbors into preferred sources of support. Many daily needs were addressed this way, borrowing items and asking favors. As in other poverty-stricken settings, mutual assistance was the primary safeguard against hardship, and local moral discourse strongly emphasized sharing and generosity (e.g., Stack 1974:32-44). ${ }^{1}$ Simultaneously, a counter-discourse favored restricting resources to the immediate family and friends and condemned others' claims to generosity as abusive. Tension between these tendencies was a focus of everyday interactions, creating a complex of duplicitous strategies and justifications that reflected different coexisting attitudes about distribution and entitlement — reflecting a significant historical shift in moral personhood, which Zygmunt Bauman (1998) suggested is characteristic of postindustrial Europe.

\section{A HISTORICAL SHIFT IN MORAL PERSONHOOD}

Bauman (1998) described a transition in European societies from "the work ethic" to a postindustrial "aesthetic of consumption." The work ethic, in his argument, served from early industrialization to commit ranks of urban poor to strenuous, lowly paid factory discipline (Thompson 1967). The moral primacy of wage labor as a "noble and ennobling activity," against which unemployment and inactivity were considered abnormal, defined one's life achievement or failure (Bauman 1998:5, 17).

A shift to more qualified services in the West made manual labor redundant. In postindustrial capitalism, the work ethic was replaced, Bauman argued, with the primacy of consumption. With decreasing demand for unqualified labor, reserves of unskilled workers became useless for economic growth (e.g., Anderson 1990:110-11; Ferguson 2013:230; Godelier 1998:11-13; Kelly 1995:227-29; contra Caldeira 2009). People are no longer called to devote their lives to labor (Bauman 1998:19), which lost its socially and morally integrative role (Ferguson 2013). Full social participation now lies in consumption, as media and advertising organize society "around desire and choice" (Bauman 1998:29, 40). Although the call to consume operates through "seduction," targeting appetites rather than moral consciences, its moral imperative is not weaker, creating dilemmas for the poor (Bauman 1998:32). "Normal" and "happy" lives rest on exercising free consumption choices, determinant of one's place in social hierarchy and of immaterial assets such as "public deference" and "self-esteem" (Bauman 1998:29, 31, 38-39; Rose and Miller 2010). With money as the gateway to consumption, poverty undermines this role. As with the unemployed of industrial times, 
the poor are morally "excluded" agents in postindustrial capitalist societies (Anderson 1990:135; Bauman 1998:37).

The economic shift from production to consumption thereby implied changes for moral personhood: how people are expected, allowed, and willing to participate, relate, and receive validation in society. In Topia, as evinced in recorded life accounts, this transition happened across one generation. First-generation migrants' narratives centered on work: what people did for a living, how they struggled to get by and raise a family, how much they enjoyed it in retrospect. Being hardworking and disliking inactivity were proudly self-reported traits of residents roughly $50+$ years of age: "I've worked all my life," "I never liked standing still," "with me it was home-work, workhome" were recurrent in interviews. More than endorsing work's virtues, work structured life stories themselves, providing the chronology and reference to assess everything else. This is epitomized in the account of a 62-year-old Cape Verdean man:

My life? Working in construction. Carpenter. Otherwise. . . Carpenter, and working in gardening. Otherwise. ... In the past, as a child, I gathered hay. With a hoe. And later, with 16, I was studying and working as a shop clerk. And that's it. Then the rest it's all here [in Portugal]. Until 16, I only did these three things. I ate corn stew, potato with fish-yes, poor man's things. Potato with fish. And I played, I jumped rope and I played with marbles, those things. That's it, with 16. The rest was all here. [Me: And here?] Here? My life, it's just working on construction. Construction. That's my story. [Me: How about other things in life? Like your family for example?] My family were public workers. They worked for the council. In the central registry. My mother was a housewife. That's it. [Me: And how about other things, other than work?] Other than work . . . ?

Other things other than work. ... I think there's nothing.

Wage labor was the focus of older migrants' self-presentation as worthy social beings, and it was evoked to criticize younger generations for failing to fulfill the same role. Among younger generations, in turn, social validation instead came from money and the things it can buy: fashion, stylish furniture, a car, lavish parties. Younger adults chose employment options on the basis of how "tiring," "far," or "pleasant" the work was, and above all, the salary. A decrease in available jobs, allied to new welfare options, created new livelihood strategies (e.g., combining welfare with odd jobs, selling drugs, stealing), which did not diminish one's status as "good people" or appreciation by one's peers. A 24-year-old informant shared the tale of a young man sentenced to 16 years in prison for robbing armored vans transporting money, concluding that: "He's a good guy, an excellent person really." Similar remarks abounded about men imprisoned for serious offences. Of a man twice arrested for theft, currently in prison for check forging, his 26-year-old ex-wife, convicted for depositing one of his checks, spoke fondly: "He's a good guy, his only problem is being a ladies' man." The primacy of income and satisfaction was also apparent in second-generation individuals' life ac- 
counts, namely in reported life goals: getting a car, a driver's license, a house, being "happy" with one's partner and children. Whereas first-generation priorities were shaped by the "work ethic," their children prioritized money and commodities. The implications of this contrast went beyond occupation or livelihood to differing moral claims about distribution and social responsibility.

The shift to consumption accompanied, especially since the 1980s, an increasing prominence of neoliberal rhetorics of thriftiness, entitlement, and ethical self-government (Rose 1989), which vilified social "dependence" (Ferguson 2013). Against the logic of collective welfare, individuals became "obliged to be free," autonomous agents in pursuing self-fulfillment (Rose 1989:224-28). European welfare systems followed this trend, tightening means-testing, inspection, and positive differentiation, and actively promoting beneficiaries' autonomy regarding employment (Bauman 1998:49-50; Moffatt 1999:235). Dependence became a "dirty word" (Bauman 1998:84-86) as individuals claimed responsibility for their fate, eroding society's responsibility and making the poor liable for their condition. In Topia, this moral shift was manifest in an evident duality between coexisting claims to share and withhold, and everyday strategies to handle this duplicity.

\section{DISCREPANT MORAL CODES}

Claims of neighbor assistance in Topia competed with complaints and efforts to limit these claims. Residents publicly defended sharing and supporting neighbors in need, while privately criticizing neighbors' claims and the duty to share as abusive and unfair. This section will describe local codes of assistance, and the criticism and distancing rhetoric they motivated.

Neighbor relations rested crucially on asking and doing favors. These included borrowing items, asking for supplies, errands, and small services: a travel card, a ride in a car, watching the children, helping to cook for a party (Stack 1974). Most visits and phone calls I witnessed had the purpose of asking or doing favors. Among relatives and close neighbors, a moral imperative existed not to refuse these requests (Bloch 1973:79-80). They were answered with a primary concern of maintaining interpersonal support ties in the long term — which did not imply direct reciprocation, as much as demanding that one's requests not be denied.

Certain circumstances carried the obligation to share without prior request. Food had a special role: people should always be directly invited to eat. "You don't ask people if they want it, you just set a plate in front of them." Sharing was also expected of anything one perceivably had plenty of (Sahlins 1972:211) — for example, garden vegetables: after harvesting, produce was offered around in one's circles of assistance. Offering drinks or cigarettes followed the same logic: when getting paid or buying a new pack, neighbors were expected to share. Solidarity expectations were also stronger around illness and death. Neighbors visited each other in the hospital and offered help or money when needed. When somebody died, especially in Cape Verdean families, wide networks of relatives, friends, and neighbors paid respects to the family. For Cape 
Verdean death rites, families kept the house open for a week, during which people visited to grieve and pray. Some days after one demise, a middle-aged white informant complained about being exhausted from spending the night with the grieving family. I asked if she was related: "No, but I'm from the neighborhood, it's the same thing." Neighbors also assisted with practical chores: watching children during the vigil, preparing food for visitors. The largest visitor contingent arrived on the funeral day, requiring tireless support from female neighbors to cook, serve, and clean.

Expectedly, the strength of moral demands reflected the relationship and social distance between people involved, creating highly contextual giving patterns (Bloch and Parry 1989:9; Sahlins 1972:191, 202). Distance was importantly defined by kinship and residential proximity: living or having lived nearby (Stack 1974:97-98). Demands and requests were stronger within the family and among people from the same slum. But daily routines gradually widened them to neighbors from different slums and their networks: relations developed mainly with those living close by (e.g., in the same building, block, or street).

The importance of living together translated to mapping "relatedness" and addressing neighbors by kinship terms (Carsten 1995). Large families, with many children per woman (by different partners over time), widened networks of ties based on affinity and co-parenthood, often residing in one or nearby settlements. People in Topia acknowledged linear, collateral, and affinal relations, which extended to former partners with whom one had children and their relatives, as well as ritual ties between godparents, godchildren, and the godchild's parents. For residents not directly related, proximity was often established through fictive-kinship terms ("uncle/aunt" for elders, "niece/nephew" for younger generations, "cousin" for age peers), and significantly, when all others seemed inadequate, people employed the term "neighbor." Since sharing demands rested on social proximity, these terms were commonly used when making claims or requests.

While upheld in discourse and reinforced in relatedness idioms, neighbors' claims to sharing were targets of private criticism, especially among the second generation. A case in point was criticizing the Cape Verdean habit of serving food on death occasions. A 30-year-old resident condemned the neighbors eating "as in a party" without compensating the family, claiming that at her funeral "nobody will eat without paying" and that food should be "just for family." At a funeral, another 29-year-old resident condemned the custom as "abusive," confessing her generation would end it if only "the old folk" would let them. Young women around her nodded while eating the family's food, highlighting the double bind toward these expectations.

Claims to restrict sharing to family or close circles abounded. One warm Sunday, a 24-year-old resident, Denise, organized a barbecue with a group of close female neighbors, collecting $€ 3$ from each for expenses. They sat outside Denise's building chatting and eating while the meat grilled. A group of young men were drawn to the grill and sat uninvited, asking for meat and drinks. Denise was upset but did not deny them. They could probably see it, because one man went over with $€ 10$ and a mock- 
ing smile: "Won't you give me a sausage?" The other men laughed, while she served him without charging. After the barbecue, women condemned the men joining in "without contributing," and Denise vowed to make future parties "just for us."

Frequent inconsistencies between sharing demands and claims to restrict them were expressed privately, but without detracting people from publicly giving. Similar complaints and contrasting conduct were common in first-generation circles who regularly barbecued on the street, sharing while condemning abusive others who ate without "contributing." "Abuse" was framed under a moral rhetoric of unfairness: taking without giving. Similar arguments were deployed in rarer occasions when people directly refused someone: the right to withhold was established by claiming others refused first, as illustrated in the following conversation between two middle-aged unemployed neighbors. Folha came to ask Ivone for a cigarette, who as usual claimed not to have any. He was certain she was hiding them and argued: "You know I give you mine when I have them." She objected he had refused her "the other day." He contended: "That's because you had a brand new pack and told me you wouldn't give me any." Ivone retracted: "It's not because you refused me, it's because of people's attitude" - for example, her neighbor had failed "the other day" to give her a cigarette. "How many packs have I given her? Nobody gives me anything," she concluded, implying it was fair to deny others the same way. Folha empathized: "I keep two or three [cigarettes] for joints, the rest I buy loose [rolling tobacco] because nobody wants that." He conceded: "I'll roll you one if you ask me. But others I say I'll give'em one if they roll it themselves: nobody wants to.”

Evoking moral fairness as grounds to avoid sharing shifted entitlement from poor neighbors or the neighbor collective to close groups: "just us" (Grassi 2007:138). Consistent with rising "notions of "self-accountability" " and "self-propelled achievement" (Fikes 2010:64; Weeks 2012:7-9), protest against unfair sharing demands contradicted daily lecturing on its virtues.

Sharing claims were also opposed by establishing social distance: demoting neighbors from close relations to distant ones. Complaints about being disappointed by unreliable others reduced the legitimacy of their claims, once again by evoking unfairness. A 32-year-old single mother considered what would happen if she won the lottery: "The first thing I'd do would be to leave, quietly, with my children, without anyone knowing. Because if they found out it'd be dangerous for me, everyone would want something." She had come across "€1000" some years before and recalled bitterly: "Before people didn't care, even my family, because I was the poorest daughter. Suddenly they wanna hang out with me, get to know me, go places with me." She concluded: "You can't rely on anybody. ..."

Although portraying others as undependable justified not giving, it did not, interestingly, excuse openly refusing. Instead, people tried to hide their possessions to avoid sharing them. She spoke of leaving quietly so that people would not "find out." Similarly, when telling me about a large sum she would receive from social security, a firstgeneration resident happily made plans to furnish her house and buy her children a 
computer, quickly growing wary when an NGO worker mentioned it outside the café: "Now there'll be plenty of people knocking on my door-'Oh, I have a problem,' 'Oh, can I borrow this?'-No way!"

A "peculiar combination of neighborliness and self-defense" fostered some distance (Anderson 1990:80) and made people believe they could not rely on others beyond close family. But amid pressing daily needs, this belief coexisted with strong prescriptions of assistance, especially enforced by older generations. Attitudes such as not refusing people food even while resenting them for joining uninvited illustrated this duality well. But discrepancies between norms and private claims, between behavior and intention, called for caution about the "dangers" in social interaction, feeding the idea that people had no "true" friends and could not get too close to others. When asked where they had met their closest friends, informants consistently distinguished "friends" from "acquaintances," claiming to have only the latter:

Friends are my mother, my sisters, and my children. Because them, I know that if something happens to me, or if I fall, they'll always reach out a hand to help me rise. But friends, I don't have them anymore. I've hurt a lot because of friends, I've been disappointed because of friends. I don't have friends. I've acquaintances. But my best friends are at home. Those are indeed my friends. . . As for the rest, I have no friends. I really don't.

A related concern arose about "not getting familiar" (não dar confiança) with neighbors, which some people advised and confessed to doing. Although keeping a distance was hardly normative or desirable, people made ostensible efforts to display nonfamiliarity: looking afar, acting uninterested, and repeatedly ignoring somebody when they spoke. Aloofness was meant to avoid unwelcome interactions-inconvenient questions or topics, uncalled-for advice. Efforts to create distance undermined the kinds of proximity established through relatedness terms and increased residents' sense of isolation: "You can't rely on anybody."

A delicate balance existed between conforming to neighborly codes and following more exclusive claims about entitlement (Godelier 1998; Jacobson 1985). Polarized reactions to sharing expectations-conceding and rejecting them, underscoring both proximity and distance- translated the duality of conflicting moral codes. This discrepancy created duplicitous practices of hiding and evading to avoid sharing without directly refusing, while keeping others' similar strategies in check through gossip and surveillance.

\section{MANAGING DISCREPANT MORAL DEMANDS}

Generosity demands were often frustrated when deemed excessive, without "contributing" in return. But failures to receive also caused, in turn, disappointment and insistence on the petitioner's end (Åkesson 2011:334-37). Insistent begging from destitute and unemployed neighbors was the other face of generosity codes. In front of cafés and 
food vendors, the familiar tune "Aren't you buying?" (não paga nada?) aimed at persuading neighbors to pay for beer, coffee, or food.

It was often the same people (with some steady income) being continually approached by the same struggling neighbors. An old shoemaker was asked daily for beer by unemployed neighbors when he sat by the café. He sometimes offered, but was otherwise hassled_-“Come on, one beer!"- until he agreed. At street barbecues, a roadworker was often persuaded to buy the bread, drinks, or cigarettes. The same happened with retired pensioners being asked for food by unemployed women regularly joining their table uninvited.

While some neighbors were known to have a steady income and entered this onesided generosity, many found themselves in either position (asking or being asked) depending on circumstance. Expectedly, people tried to establish some prior relationship before feeling entitled to ask: begging was not directed at just anyone, but mostly close neighbors. Relatedness was often evoked (though sometimes countered by distancing rhetoric). If prior ties did not exist, the effort was made to affirm one's destitution and establish familiarity over time. I had recently met Luzia (a white middle-aged resident, unemployed, and mother of two), who often complained to me about money and stressed how much she struggled. Months into my stay, at a street event, I spotted Luzia and went to greet her. I was eating and offered to buy her food. She smiled mischievously and guided me to a drink stall: "Won't you buy me a beer instead?" Some weeks later, on a similar event, she came over to ask familiarly: "Aren't you buying?"

Grounded on persistent asymmetry, continual begging was often considered abusive. People tried to dodge it without jeopardizing support networks and codes, devising strategies to hide their possessions and thus avoid giving without directly refusing. On the vendors' corner one afternoon, Ivone, an unemployed middle-aged resident, suddenly left the group to head home. She showed me a cigarette pack she kept hidden in her coat. Up in her flat she lit up a cigarette, again hiding the pack and leaving. On the stairs a neighbor saw her smoking and asked for a cigarette. Ivone regretted she did not have any more, but gave the neighbor the one she was smoking as proof of good will. Later that day, as Ivone had discretely reached for another cigarette and smoked it outside, a man walking by asked for one. She again denied having more and pointed to a man smoking further down the road, claiming she had gotten her cigarette from him. This made the first man chase after the second to beg him for a cigarette, while the smoker insisted he did not have any more.

Residents struggling with small earnings were particularly careful to hide them. One of the most destitute women I met admitted she always took the longer route around Topia to reach the city on the day welfare checks arrived, to avoid neighbors asking for things on the way. People considered carefully where to walk or park when returning from shopping trips, to minimize intrusiveness and gossip about bags and purchases, often using the underpasses instead of the main road. Neighbors also hid the availability to help, pretending not to be home, or used vague and indirect ways to avoid helping, pretending not to listen, indefinitely stalling ("I'll go in a minute ..."), or offering 
faint excuses. Another common strategy was to stress one's hardship. I grew used to Ivone's out-of-context remarks about being broke when passing neighbors on the stairs: "This month I'm not paying for water or electric, there's no money"; " $€ 10 \ldots$ I don't have it now, I'll pay the grocer at the end of the month."

But hiding and avoiding made petitioners alert. It spurred monitoring of others' earnings and spending, and their failures to be generous. People looked out for purchases, clothes, new furniture, signs of paid wages or benefits. From street corners, sitting by building entrances, or looking through windows, mostly unemployed neighbors followed others across the estate, paying attention to bags and items carried, or any anxiety over mail arrival (meaning impending welfare checks). These discreet routines were clear to residents (Stack 1974:37-38): "See that woman at the window? She's always there this time of month. When she's gone it means the postman's come. She's got her bag ready, as soon as the check comes she's out shopping." "See that car that drove down? Those people just went to cash their checks."

But all this gazing was itself noticeable, and a focus of criticism. Residents were aware of being watched and recognized the power of neighbor scrutiny. Connections between gazing and power are well established (Foucault 1980, 2008). Visibility acts as a "disciplining" mechanism, inducing adjustment of apparent behavior in those aware of being watched (Foucault 2008:7). Residents tried to be less visible to escape the "control" of street gazers: using underpasses instead of the main road, detouring through emptier streets or even around Topia. This had limited efficacy, as neighbors also peeked through windows. Window gazing was openly condemned. Women shut curtains and lights before looking out, to avoid being seen. People seen watching from windows were confronted. A middle-aged interviewee complained that "in the beginning we couldn't be at the window": neighbors accused them of "talking about their lives, they'd call us gossips, call us this and that." As in the border community researched by Amster, in Topia social routines were entwined with "issues of visibility and invisibility: what and who is seen by whom, how public and private space is constructed, and the forms of social optics and surveillance by which people monitor (and fail to monitor) each other's behavior" (2008:176). Scrutiny curtailed efforts to hide and excuse, and made moral failures the object of abundant gossip (Scott 1976:40).

Ethnography has illustrated gossip's varied and highly contextual roles, inseparable from "the blood and tissue" of local life (Hannerz 1967; White 1994:76). In Topia, gossip and gazing were central tools of moral control enforced by both men and women, allocating "responsibility" and enforcing "ideas about deviance and virtue" (White 1994:77-78)—obsessively scrutinizing resources and condemning efforts to keep them private. Stories of resource accumulation, selfish spending, and refusals to share were recurring moral tales, especially amid unemployed or retired residents, more regularly present on the streets. A circle of neighbors showed outrage when an elder woman who allegedly had "a lot of money" paid " $€ 1000$ " for eye surgery: "at that age, what is she still gonna see?" Gossip's topics revealed main local concerns, "the issues and questions and theories that circulate about humanness and reality" (Van Vleet 
2003:494), which in Topia centrally revolved around income, social obligations, and their failures. Gossip and gazing enforced the virtues of sharing against avoidance strategies and individualistic claims.

I have described a moral ambivalence between neighborly duties and self-accountability claims. That same ambivalence extended to gossip. Just as people could be on either side of begging, they found themselves both engaging in, and condemning, gossip. It was an object of criticism even as it pervaded conversation: censuring others often involved censuring gossip itself. Two unemployed women sat by the road criticizing "the gossips," idle female neighbors known to sit outside "bad-mouthing" others. One woman claimed she quit hanging out with these women when she found out they gossiped about her. The other agreed. They condemned "idling around," stressing they never did it, even while they lingered on, watching the road.

\section{UNCERTAINTY AND DUPLICITY IN PERSONHOOD}

The ambivalence surrounding gossip and gazing was the evident counterpart of the ambivalence surrounding sharing and entitlement. Just as generosity was enforced while privately opposed, scrutiny over others was both condemned and covertly exercised. These discrepancies were resolved through secrecy. Hiding one's feelings and resources enabled some reconciliation between enforcing and restricting sharing expectations. Information circulated in close groups, veiled in the presence of others by using vague terms and not mentioning names. As with relatedness terms, gossip was an "idiom of intimacy," consolidating group belonging by building trust and excluding "outsiders" (White 1994:76, 79). Questions were ostensibly ignored. So people groped for updates without openly asking, enabling them to dodge accusations of minding others' business. The morning after a fight broke out in front of the vendors, a man approached a female neighbor, hoping to learn details. He mentioned the subject, appearing nonchalant. She replied vaguely, not adding information. He quickly averred: "I don't know anything." She concurred: "I didn't see it either." As he left frustrated, she muttered: "If you're after the news, go read the paper: my mouth stays shut."

However, secrecy did not really prevent information from spreading, nor people from knowing that others gossiped about them: "Don't tell anyone I told you" was trivial advice. Contrastingly, Topia was known as a space of gossip. People reproached "the atmosphere" of idling residents sitting outdoors monitoring and talking about neighbors. The scoffing remark of a 16-year-old girl when I explained my interest in local culture said it all: "The culture of Topia is sitting in corners talking about other people's lives."

The dissonance between what was publicly said and privately done, and the awareness of being "controlled" and criticized, made people wary of neighbors' "true" intentions. Duplicity and concealment caused mistrust, highlighting "discrepancies between 'impression' and 'reality”" (Hannerz 1967:38). The resulting tension weakened sociality, brewing the notion that people could not be trusted. Social relations were "embedded," as it were, "in an atmosphere of distrust" (Stack 1974:39). An elder migrant 
complained about staying home nowadays instead of going to the café since she realized "People flatter you in the face to then stab you in the back." I found widespread beliefs that envy and malice pervaded Topia, and that "true" friendships were hard to keep. Receiving phone calls from unfamiliar numbers or strangers chatting on Facebook raised alarm over who they "really" were: they "could be an enemy."

Assumptions on the dangers hidden in the social world were centrally linked to wealth disparities. An unemployed Guinean woman resented how better-off neighbors treated poorer ones:

Those who own don't help those who have none. Those who own think "Oh, just 'cause I own doesn't mean I must help others." ... Just now I'm talking about my life, and I have nothing! I wanna buy a piece of bread and I can't. But who knows if I'll have something tomorrow? I don't! So there's no point in so much evil, there's no point in so much envy, no. We're all the same, the only thing that changes is a difference in skin, but skin isn't what matters. What matters is the heart, what's inside. In my country they always say that "Everything beautiful on the outside, is rotten on the inside." It's better for the inside to be beautiful than what's outside. [Me: Do you feel there's evil here in people?] I think there is. I think there's much, much envy, a lot.... A lot. ... That's what everyone thinks: because they own, that they own the world.

Her views of much "envy" and "evil" in Topia were connected to neighbors' refusals to share. They remained hidden at "the heart," the level of intention—consistent with concealment practices. Contrast between outer and inner (invisible) dimensions permeated local theories about personhood and the dangers in proximate relations: neighbors could cause harm. When I told a young Cape Verdean woman my early plans to visit Cape Verde, she advised me not to tell anyone until everything was set: "There're people with a big eye and all that. ..." In keeping with local beliefs about witchcraft, the evil eye, and the harm concealed in others, she explained her projects sometimes failed when she shared them with others because of people's "envy." These beliefs were stronger among Cape Verdeans but were pervasive among different groups in Topia. Duality in social relations was traced to people's duplicitous nature-a prominent feature of witches, "the epitome of the divided self," in "a world divided between surface appearance and actual intention” (Munn 1986:231, 264-67).

Several objects and substances were used in Topia against witches and the evil eye, particularly to protect children. They included sibitxi (dotted black beads worn in necklaces, bracelets, and earrings), aloe vera, rue, garlic, creosote, and holy water. Second-generation individuals related to these procedures with mixed deference and dismissal, and witchcraft was hardly discussed outside familiar circles, contrasting with its prominence in daily life. A Cape Verdean woman declared there were no witchcraft experts in Topia, adding: "Even if there were, they'd never admit it." But shifting the focus to people's complaints of being witchcraft victims, she conceded: "Oh, that 
everyone says." Embarrassment and secrecy about witchcraft contrasted with its pervasiveness, confirming the dangers hidden in neighbor relations.

A connection is well established, for small social settings, between social conflict, wealth disparities, and gossip, on the one hand, and witchcraft beliefs, on the other (Stewart and Strathern 2004). Witches epitomized in Topia the ambivalence in moral codes and persons. Witches' envy_ "the anger of the excluded"-represented unrestrained demands for others' resources, yet operating furtively in "secret acts" of selfishness and concealment (Munn 1986:221). Witchcraft beliefs articulated in an exacerbated manner the duality of demanding and concealing, and its immoral nature. In Topia these beliefs incorporated theories about social relations and their duplicity. Yet they did not spur, as could be expected, public accusations or trials for social purging and conflict resolution (Stewart and Strathern 2004:x-xii), or even public discourse against witchcraft (Munn 1986:217-18). Fear of others' envy or resentment made neighbors safeguard against them, but not address witchcraft as a fundamental social problem. This suggests witches and their actions were not seen as ultimate or effective explanation for "evil" and conflict (Stewart and Strathern 2004:xii). Instead, this duplicity in morals and persons, as argued below, was explained through narratives about space.

Mistrusting people's intentions extended to anxieties about stealing (Munn 1986: 224). Media representations of immigrants and ethnic minorities in Portugal in recent decades have emphasized images of crime and deviance, creating overly negative portrayals (e.g., Cunha and Santos 2006; Cunha et al. 2004). Topia residents were aware of these representations and employed terms such as "problematic" and "degraded neighborhood" to refer to Topia, the old slums, and other migrant settlements (Barbosa and Ramos 2008:176, 178). Some residents considered these portrayals unfair. Nevertheless, 13\% of households surveyed in 2010 reported being victims of robbery or theft inside the estate, while $48 \%$ considered Topia "unsafe" or "very unsafe." At cafés and parties people advised me to be cautious about my belongings: "They steal everything!" Concerns about stealing were also apparent in post boxes, where metal or wood strips were added to narrow the openings. Waiting for her welfare check, Ivone explained this practice while peeking into neighbors' boxes to confirm whether their checks had arrived: "Otherwise they'll tuck a hand in."

Regardless of its accuracy, the perception that "they steal everything" further nurtured the atmosphere of mistrust. Feelings of insecurity added to anxieties about duplicitous motives, envy, gossip, and surveillance. They fostered discourses of "disappointment," discredited "true" friendships and proximity, and created uncertainty about persons and their "real" nature and intentions. In this scenario, models of persons hardly provided solid grounding to conceive (discrepant) morals (Hickman 2014). Conversely, moral ambivalence — sharing while avoiding, monitoring while hiding, criticizing while doing - engendered notions of shifting, divided, duplicitous persons. This moral and ontological uncertainty was reimagined and theorized through contrasting models of residential space: shanties versus buildings. 


\section{SPATIAL ANCHORS TO MORALS AND PERSONS}

Disappointment at neighbors' shortcomings and duplicity often turned to themes of housing and the past. Among men and women of different ages and slums, in interviews or everyday conversation, a collective discourse circulated contrasting life in the old shanties against current life in buildings. A surprisingly consistent narrative identified slum life, across different slums, with "unity" in neighbor relations, whereby "doors were always open" and neighbors easily borrowed what they needed; as opposed to Topia, where people "shut themselves at home," rarely socialized, made excuses not to help, and did not really know each other. Residents portrayed an idyllic life in the shanties: people were available to help, they "controlled" neighbors' children ("if they've eaten," "if they're doing their chores"), they "controlled your pot on the fire," whereas "now they say they can't." People gave different reasons for this apparent shift. "Nowadays life is different, people are different": previously racism made people keep more to the neighborhood; now rent and bills forced women to work outside the house; now life was more expensive; now neighbors were unfamiliar.

The perceived decline in neighbor assistance set Topia against the old shanties as polar scenarios of different kinds of neighbors and ties (Weeks 2012). Not all aspects of the move were seen as negative: most residents acknowledged improved infrastructure and sanitation. But they concluded that if given their current house in the old neighborhood, they would have rather stayed there. ${ }^{3}$ A Cape Verdean woman expressed this trade-off and sense of loss:

When we moved here, I was glad. Because many people lived in destitution, in subhuman conditions really. And these houses are much better in infrastructure. But we also lost much of our culture, our way, the neighborhood we lived in. Because we were much more solidary with each other, we were closer, in other words: in [the slum] we never closed doors. We always had the doors open. Any place, any street, any alley you'd go, doors were never closed. Not here. Here, people are forced to close the door because ... I don't know. First of all, the aesthetics of the neighborhood is different. And secondly, I'll just give you an example: I hardly know neighbors in my building.

The "open door" was a pervasive theme. It seemed to stand, in residents' imagination, for the openness of people and their relationships. Open doors ensured neighbors were connected and nobody was left alone. The same informant continued:

Since we didn't close doors . . . if our next-door neighbor had a hungry child or nothing to eat, we could tell and what little we had, we could share it. But here that doesn't happen. Here if somebody feels ill or hungry at home, we can no longer tell. . . . Loneliness doesn't exist in the shanties. It never existed in the shanties. Never! Because no matter how bad off we are, we always reach out a hand to each other, we always share. But here it's different. Here there is loneliness. . . . 
Keeping doors open was directly associated with housing structure: as opposed to shanties, buildings seemed incompatible with open doors:

In buildings, it's impossible to have the door open. Because. Well for starters, it attracts burglars. And further because. . . . How should I put it? For example, if you look at rehousing buildings, doors outside are all damaged, the doorbells, it's all damaged. Because. I think the building itself doesn't give people that ease and trust to keep the door open. Because we don't know our neighbors. . . . Because here we were rehoused together with other neighborhoods, we don't have that kind of trust to leave the door open, because we don't know who lives next to us, what kind of people they are. There in [the slum] it was different, we were practically a family.

Residents gave different reasons for seemingly decreased sociality after the move. These factors partly resided in important socioeconomic changes: higher living costs (Pinto 1994:42; cf. Bourdieu 1979:83ff.), women's participation in the labor force, and changes in racism and segregation. People from different slums were also rehoused together, perceivably deteriorating "ease and trust." Feelings of insecurity and mistrust, addressed above, accompanied the idea that "we don't know who lives next to us, what kind of people they are." Neighbors now perceivably included people capable of robbing and vandalizing property. ${ }^{4}$ Evoked closeness and interdependency gave way to feelings of isolation and "loneliness."

Perceived transformations in people and conduct, linked to different factors, were ultimately conceived and explained through transformations in housing. Housing structure - "the building itself" — was responsible for undermining social ties. Mistrust and disappointment was centrally traced to changes in housing type. Newly felt insecurity and isolation were ascribed to building life, where doors were closed and one could not tell what was happening with neighbors. The "open door" was a pervasive metonym of slum life. It symbolized the ideal openness and unrestrained flux of resources and people, sharing and relating as "practically family," because house and street had no real separation: "We always reach out a hand to each other, we always share."

Freitas (1994:29) suggested that shanties made the street their natural extension, opening "domestic life to community life" without leaving the house (cf. Bourdieu 1979:88-90; Mitchell 1998). In buildings, adjacent spaces lost their function (to wash, hang clothes, grill meat) along with "symbolic" and "sociability-supporting" dimensions, closing households off from the street's relational roles (Freitas 1994:29). As closed doors kept neighbors apart, significant social losses were seen to happen (from an interview with a 50-year-old Cape Verdean woman):

We lost our sociality with people. [Me: How was it?] Doors were all open. With neighbors, if we didn't have salt, we'd ask “Oh neighbor, don't you have a pinch 
of salt, a pinch of sugar? Oh neighbor, don't you have an egg?" It's always ... She never says no. And the door is open, we could go in and take it. It's a sociality we can call family sociality. Which is broken here [in Topia]. There's no sociality. People here are all selfish! [Me: But they're more or less the same people here right?] They're the same. [Me: So what do you think changed?] It changed because. . . . Even their attitude. I don't know if it's because it's a building, because people are in a building? People changed their attitude, they're more arrogant.

In residents' accounts, buildings created barriers to "sociality" and "family"-like relatedness (Mitchell 1998:87-89). In buildings, the "same" neighbors seemingly became "selfish" and "arrogant." This explains why Santos, quoted earlier, wanted to "blow up" buildings and move the people to different houses. He reacted against the perceived evil and loneliness in Topia by attacking its core cause: buildings, rather than people.

In buildings, visits also allegedly became less frequent and spontaneous as routines shifted from an outward-extending house to a confined one (Freitas 1994:30). With closed doors, people needed reasons to visit:

After coming here, everything changed. People changed, that sociality we had in the neighborhood [slum] doesn't exist anymore. In the old days in the neighborhood I could leave the house, the door was always open, nobody had any problems. Because we knew everybody, children, youth, we knew everyone. And we always got along well. ... But to go to somebody's house [in Topia], there's a certain barrier, I don't know. I think many people when they came here, they severed ties, that thing of frequenting each other's houses. To go to somebody's house, if they're not really my friends, I won't go.... That's something that didn't exist in the neighborhood. We were always together, we'd meet on the street, People here are, I don't know. Things had to change. ... I think there's also the influence of living, let's say, in a building-type structure. Which is totally different. There, because it's a shanty, I think nobody had the complex of "Oh, I have a better house," or "my house is prettier." Because here, for example if you're remodeling, others are paying attention because they think like "This one's remodeling, it's because she has money and ..."--that's not the point. (Interview with a 38-year-old Cape Verdean woman)

Another aspect seen to deteriorate neighbor relations was something a social worker called "the dazzle of buildings": people's "complex" of striving for a prettier home and monitoring neighbors' decor (cf. Bourdieu 1979:90-91; Young and Willmott 1957: 129-33). New houses became "recipients of material and affective investments" (Pinto 1994:37, my translation), "symbolic markers of social status," seen as "opportunity for social promotion," reflected in concerns about style and decor (Rodrigues 2003:9697). For socioeconomically marginalized households, upgrading to mainstream hous- 
ing was seized to affirm social advancement, creating social divisions previously absent (Rodrigues 2003:97). When Ivone considered writing to a TV show to ask for help refurbishing her house, she rejoiced at the thought of neighbors "filled with envy, thinking I'm rich." In turn, she complained about her next-door neighbor attempting, under false pretense, to "peek" at her living room after she painted the walls: "She wants to imitate me!" Another informant mentioned the issue to explain why buildings changed people:

Because there [in the slum] it's neighborhood, not buildings. Buildings change people because you get inside the building and you close the door. Each person goes up to their floor. You don't see them. Not there [in the shanties]. There, there're no floors, there it's house next to house. Like that, really close. You just go out and you're watching your neighbor leave the house. Not here in the building. You're going out, you see no one. You go in, you might not see anyone. There, there's no one who won't notice you. [Me: And couldn't you have the doors open here like that?] No, because ... it's different. Because here, many people are at work and they don't have their. ... It's very hard to explain. Because here if you have your house open, you have other sorts of things inside. Like in the slum, many things weren't bought because people were afraid to ruin them, or to buy good stuff, they wanted to move to the building to get those things, they ended up having those ideas. I think it's ridiculous but whatever: "Oh no, when I move to the building I'll buy this, I'll buy that." They end up having more luxury than in [the slum], you get it?

Again central to this account was the notion that "buildings change people." Closed doors and floors interrupted neighbors' visual range and control. Horizontal space ("house next to house") connoted sociability and visibility, whereas verticality (each in their "floor") translated isolation and loneliness. She associated buildings with luxury, cultivating envy and competition. Significantly, visual "control" in the shanties was desirable (making sure people were not hungry or ill, checking up on children), whereas in buildings it became oppressive and dangerous, assuming greedy or ill intentions (coveting one's purchases, copying one's home style). Previously, one knew who neighbors were and what happened with them-now "you see nobody." The space of open doors, active ties, and support was seemingly transformed by newly erected barriers: physical, social, and symbolic. These barriers interrupted the flow of visits, items, and assistance (Foucault 2008:6), making neighbors' homes, and their intentions, opaque. My informant's clarification about the shanties was significant: "It's neighborhood, not buildings."

Rehousing was articulated as profound loss in sociality, assistance, and trust. The shift from shanties to buildings gave substance to the perceived shift in conduct and personhood, and its accompanying loss of moral certainty. Shanties versus buildings was the collective idiom for that loss: spatial transformations carried social ones. Nos- 
talgia and regret formed a moral commentary on present uncertainty, duplicity, and loneliness. Depictions of communal solidarity and control in a space now extinct expressed bereavement over the deep social transformations. Residents bemoaned the strained social environment where private claims and selfish projects undermined proximity and assistance. They lamented the false pretenses and hidden intentions, declining visits, favors, and trust, house-centered investments and petty competition, gazing and gossip made invasive to penetrate closed doors and concealment tactics. Changes in space were used to conceive profound changes in sociality, morals, and persons, and to reconcile their dual tendencies.

Anthropology's rejection of space as the taken-for-granted unit of culture (Gupta and Ferguson 1992:7) has led since the 1990s to an excessive emphasis on diffuse networks of unbounded global connections, border crossings, and a disjuncture between "locality" and space (Appadurai 1995, 2008). Yet attention to the global has at times lost sight of how space can matter precisely in its production as bounded and static. Refusal to "naturalize" borders should not entail naturalizing disjuncture or unboundedness instead. In Topia, spatial boundaries and structures mattered precisely for their postulated fixity, which allowed reconciling discrepant impulses and behaviors by projecting them onto different spaces: shanty towns and building blocks. The dichotomy provided substance to crystallize, in residents' imagination, duplicitous persons and conflicting claims into simplified poles: unity vs. loneliness, open vs. closed, past vs. present, good vs. bad. It was through its assigned stasis and boundedness that neighborhood space provided the "ontological cement" for handling the uncertainty caused by evident discrepancies in morals and personhood.

\section{NOTES}

This research would not have been possible without the generous financial support of the Portuguese Foundation for Science and Technology (FCT-MCTES), through grant SFRH / BD / 44641 / 2008, which provided me with the time and resources to undertake this research project. I also express my sincere gratitude to all the people in Topia who granted me their time, patience, and life stories. Although their real names are not mentioned here, they are the protagonists of my ethnography, and I hope to do justice to their voices and experiences. I am particularly indebted to Diana, Fabi, Leandra, Domingas, Adelaide, and Ivone, the most powerful voices informing my account, for sharing their views, concerns, and daily struggles with me, and for giving me their friendship.

1. The link between reciprocal practices and the alleviation of poverty is well known (Befu 1977:275), and assistance networks have been a solid institution in rural Cape Verde (Couto 2001), even if in cities, factors such as loss of trust, smaller families, or less free time have been found to make them less effective for survival among the poor (Rosas 2001:45-53).

2. The Creole term for the evil eye is odjada, after odju ('eye'). Cape Verdeans often translated it to Portuguese as olho (eye), olhado ('eyed'), or olhada. 
3. Guerra (1994), Freitas (1994), and Pinto (1994) address the duality of "liking the house, disliking the neighborhood" after rehousing.

4. As previously stated, I refer here solely to informants' perceptions and narratives and make no claim regarding what actual life in the shanties looked like.

\section{REFERENCES CITED}

Åkesson, Lisa. 2011. Remittances and relationships: Exchange in Cape Verdean transnational families. Ethnos: Journal of Anthropology 72(3):326-47.

Amster, M. 2008. The social optics of space: Visibility and invisibility in the borderlands of Borneo. Space and Culture 11(2):176-95.

Anderson, Elijah. 1990. Streetwise: Race, class and change in an urban community. London: University of Chicago Press.

Appadurai, Arjun. 1995. "The production of locality," in Counterworks: Managing the diversity of knowledge. Edited by R. Fardon, pp. 204-25. London: Routledge.

- 2008. "Disjuncture and difference in the global cultural economy," in The anthropology of globalization: A reader. Edited by J. Inda and R. Rosaldo, pp. 47-65. London: Blackwell. (First published in 1996)

Barbosa, C., and M. Ramos. 2008. "Vozes e movimentos de afirmação: Os filhos de caboverdianos em Portugal," in Comunidade(s) cabo-verdiana(s): As múltiplas faces da imigração cabo-verdiana. Edited by Pedro Góis, pp. 175-93. Lisbon: ACIDI.

Batalha, Luís. 2004. The Cape Verdean diaspora in Portugal: Colonial subjects in a post-colonial world. Oxford: Lexington Books.

- 2008. "Cabo-verdianos em Portugal: 'Comunidade' e identidade," in Comunidade(s) cabo-verdiana(s): As múltiplas faces da imigração cabo-verdiana. Edited by Pedro Góis, pp. 2536. Lisbon: ACIDI.

Bauman, Zygmunt. 1998. Work, consumerism and the new poor. Buckingham: Open University Press.

Befu, H. 1977. Social exchange. Annual Review of Anthropology 6:255-81.

Bloch, Maurice. 1973. "The long term and the short term: The economic and political significance of the morality of kinship," in The character of kinship. Edited by Jack Goody, pp. 7587. London: Cambridge University Press.

Bloch, Maurice, and Jonathan Parry. 1989. "Introduction: Money and the morality of exchange," in Money and the morality of exchange. Edited by Jonathan Parry and Maurice Bloch, pp. 1-32. Cambridge: Cambridge University Press.

Bourdieu, Pierre. 1979. Algeria 1960: The disenchantment of the world; The sense of honour; The Kabyle house or the world reversed. Essays by Pierre Bourdieu. (transl. R. Nice). London: Cambridge University Press.

Caldeira, Teresa. 2009. Marginality, again?! International Journal of Urban and Regional Research 33(3):848-53.

Carsten, Janet. 1995. The substance of kinship and the heat of the hearth: Feeding, personhood, and relatedness among Malays in Pulau Langkawi. American Ethnologist 22(2):223-41.

Castells, Manuel. 2004. "Space of flows, space of places: Materials for a theory of urbanism in the information age," in The cybercities reader. Edited by S. Graham, pp. 82-93. London: Routledge.

Couto, C. 2001. Estratégias familiares de subsistências rurais em Santiago de Cabo Verde. Lisbon: ICP. 
Cunha, I., and C. Santos. 2006. Media, imigração e minorias étnicas II. Lisbon: ACIDI.

Cunha, I., C. Santos, M. Silveirinha, and A. Peixoto 2004. Media, imigraçāo e minorias étnicas. Lisbon: ACIDI.

Englund, H. 2002. Ethnography after globalism: Migration and emplacement in Malawi. American Ethnologist 29:261-86.

Ferguson, J. 2013. Declarations of dependence: Labour, personhood, and welfare in southern Africa. Journal of the Royal Anthropological Institute 19:223-42.

Fikes, Kesha. 2009. Managing African Portugal: The citizen-migrant distinction. Durham, NC: Duke University Press.

- 2010. Late capitalism in Cape Verde: Commerce, migration, and privatization. Transition 103:56-67.

Foucault, Michel. 1980. "The eye of power," in Power/Knowledge: Selected interviews and other writings, 1972-1977. Edited by C. Gordon, pp. 146-65. New York: Pantheon Books. (Published in French in 1977)

—. 2008. "Panopticism" from Discipline \& punish: The birth of the prison (transl. A. Sheridan). Race/Ethnicity: Multidisciplinary Global Contexts 2:1-12. (Originally published in English in 1977; in French in 1975)

Freitas, M. 1994. Os paradoxos do realojamento. Sociedade e Território 20:26-35.

Gil, C. 2012. Relatório do sector da construção em Portugal - 2011. Lisbon: INCI (Available at: http://www.base.gov.pt/mediaRep/inci/files/oop_docs/Relatorio_anual_Construcao_2011.pdf)

Godelier, Maurice. 1998. "El don: Una doble relación," in El enigma del don. Pp. 24-29. Barcelona: Paidós.

Góis, Pedro. 2008. "Introduçáo: Entre Janus e Hydra de Lerna. As múltiplas faces dos caboverdianos em Portugal," in Comunidade(s) cabo-verdiana(s): As múltiplas faces da imigração cabo-verdiana. Edited by P. Góis, pp. 9-24. Lisbon: ACIDI.

Grassi, Marzia. 2007. Economia informal em rede: Trocas económicas e complexidade social. Caderno de Estudos Africanos 13/14:127-42.

Guerra, I. 1994. As pessoas não são coisas que se ponham em gavetas. Sociedade e Território 20:11-16.

Gupta, Akhil, and James Ferguson. 1992. Beyond "culture": Space, identity, and the politics of difference. Cultural Anthropology 7:6-23.

Hannerz, Ulf. 1967. Gossip, networks and culture in a black American ghetto. Ethnos 32:35-60.

Hickman, J. R. 2014. Ancestral personhood and moral justification. Anthropological Theory 14 (3):317-35.

Inda, J., and R. Rosaldo, eds. 2008. The anthropology of globalization: A reader. London: Blackwell. Jacobson, D. 1985. Boundary maintenance in support networks. Social Networks 7(4):341-51.

Kelly, M. P. F. 1995. Slums, ghettos, and other conundrums in the anthropology of lower income urban enclaves. Annals of the New York Academy of Sciences 749:219-33.

Low, Setha M., and Denise Lawrence-Zúniga. 2003. "Locating culture," in Anthropology of space and place: Locating culture. Edited by Setha M. Low and Denise Lawrence-Zúñiga, pp. 1-47. Oxford: Blackwell.

Massey, Doreen. 1997. "A global sense of place," in Reading human geography: The poetics and politics of enquiry. Edited by T. Barnes and D. Gregory, pp. 315-23. London: Hodder Headline.

Mauss, Marcel. 1985. "A category of the human mind: the notion of person; the notion of self” (translated by W. D. Halls), in The category of the person: anthropology, philosophy, his- 
tory. Edited by Michael Carrithers, Stephen Collins, and Stephen Lukes, pp. 1-25. Cambridge: Cambridge University Press. (Originally published in French in 1938)

Mitchell, J. 1998. The nostalgic construction of community: Memory and social identity in urban Malta. Ethnos 63:81-101.

Moffatt, K. 1999. "Surveillance and government of the welfare recipient," in Reading Foucault for social work. Edited by A. Chambon, A. Irving, and L. Epstein, pp. 219-45. New York: Columbia University Press.

Munn, Nancy. 1986. The fame of Gawa: A symbolic study of value transformation in a Massim (Papua New Guinea) society. Cambridge: Cambridge University Press.

National Institute of Statistics. 2012. Statistical yearbook of Portugal 2010 - Issue year 2011 (Available at: http://www.ine.pt/xportal/xmain?xpid=INE\&xpgid=ine_destaques \&DESTAQUESdest_boui $=107966729 \&$ DESTAQUES)

Pellow, Deborah. 2001. Cultural differences and urban spatial forms: Elements of boundedness in an Accra community. American Anthropologist 103:59-75.

Pinto, T. 1994. A apropriação do espaço em bairros sociais: O Gosto pela casa e o desgosto pelo bairro. Sociedade e Território 20:36-43.

Rodrigues, J. 2003. As lógicas sociais dos processos de realojamento. Cidades-comunidades e territórios 7:91-99.

Rosas, R. 2001. Social networks and urban poverty. Development and Society 30(2):41-56.

Rose, Nicholas. 1989. Governing the soul: The shaping of the private self. London: Routledge. Rose, Nicholas, and Peter Miller. 2010. Political power beyond the state: Problematics of government. British Journal of Sociology 61:271-303.

Sahlins, Marshall. 1972. "On the sociology of primitive exchange," in Stone Age economics. Pp. 185-230. Chicago and New York: Aldine Atherton.

Scott, James. 1976. The moral economy of the peasant: Rebellion and subsistence in Southeast Asia. London: Yale University Press.

Stack, Carol B. 1974. All our kin: Strategies for survival in a black community. New York: Harper \& Row.

Stewart, P., and A. Strathern. 2004. "Foreword," in Witchcraft, sorcery, rumors and gossip. Pp. ixxiv. Cambridge: Cambridge University Press.

Thompson, E. P. 1967. Time, work-discipline, and industrial capitalism. Past and Present 38: 56-97.

Van Vleet, K. 2003. Partial theories: On gossip, envy and ethnography in the Andes. Ethnography 4:491-519.

Weeks, S. 2012. Marxian crisis, Maussian gift: The mutual-help practices of Lisbon's Cape Verdean labor immigrants in an age of austerity. Cadernos de Estudos Africanos 24:27-43.

White, L. 1994. Between Gluckman and Foucault: Historicizing rumour and gossip. Social Dynamics 20(1):75-92.

Young, M., and P. Willmott. 1957. Family and kinship in east London. London: Routledge and Kegan Paul. 